\title{
Cosmopolitan Democracy: A Restatement
}

\author{
Daniele Archibugi
}

\section{What is cosmopolitan democracy?}

Cosmopolitan democracy is a project of normative political theory that attempts to apply some of the principles, values and procedures of democracy to the global political system. As a consequence of the fall of the Berlin Wall, democratic regimes have spread in the East and in the South. For the first time in history, elected governments administer the majority of the world population and, although not all these regimes are equally respectful of basic human rights, there is a significant pressure to achieve representative, accountable and lawful administration. Democracy has become, both in theory and in practice, the sole source of legitimate authority and power.

The victory of liberal states should have produced another equally important development: the expansion of democracy as a mode of global governance. But, unfortunately, the rules of the international system have changed little. Global political affairs continue to be dominated by raison d'etat. Issues concerning war and security are still in the hand of national governments that, as in the past, take decisions autonomously. In spite of the increasing web of interactions among governmental and nongovernmental players, the bulk of contemporary political choices are taken within states. And even if coordination in international decision making is increasing, it is not subjected to democratic procedures but rather to the relative strengths and interests of the various players.

This state of facts generates a major contradiction: democracy is preached as the universally superior political system of the global age but globalization is not ruled according to democratic values. In addressing this issue, cosmopolitan democracy is an attempt to combine the important progresses achieved in democratisation within states with the need to apply also some of the principles of democracy in the international scene ${ }^{1}$.

\footnotetext{
${ }^{1}$ Daniele Archibugi, David Held (eds.), Cosmopolitan Democracy. An Agenda for a New World Order (Cambridge: Polity Press, 1995); David Held, Democracy and the Global Order (Cambridge: Polity Press, 1995); Richard Falk, On Humane Governance: Towards a New Global Politics (University Park, PA: Pennsylvania State University Press, 1995), Daniele Archibugi, David Held and Martin Koehler (eds), Re-imagining Political Community: Studies in Cosmopoli-
} 
Cosmopolitan democracy is based on two assumptions. The first is the empirical observation that states are de iure sovereign but de facto non autonomous ${ }^{2}$. Environmental threats, contagious diseases, trade, terrorism and migration make it more and more difficult for states to be truly independent. Each political community has to cope with phenomena that take place outside its territorial jurisdiction and for which it has no direct accountability and control. In these circumstances is becoming increasingly difficult to preserve meaningful democratic decision-making within states. If the democratic principle of involvement and equality of all members affected by decision-making shall be preserved, the boundaries of political community should be re-thought. This, in turn, requires a rethinking of some of the basic principles of democratic practice and organisation, which has so far been based upon the existence of territorially delimited communities, where the participation of individuals in the democratic procedure is disjunctive (the individual belongs to community A or community B, but not to both, and therefore can participate in the democratic process either of $A$ or $B$ ).

Although globalization put states' democracies under stress, it also provides new opportunities that can be used also in political life. New information and communication technologies are opening the gates to a genuine global public sphere, and it has become technically feasible for communities living in remote parts of the world to take part in the same deliberative process. Such deliberations are already happening in elite circles such as professional associations. But they can also involve the global demos as a whole, especially when issues that affect the destiny of all humanity (such as environmental and security issues) are at stake.

The second assumption is that the foreign policy of democratic states is not more virtuous than those of non-democratic states. Even the most democratic states can be aggressive, selfish, and prepared to defend their vital interests by unlawful means, and the invasion of Iraq has sadly confirmed this belief. History provides large abundance of aggression wars perpetuated by democratic regimes as well as by despotic ones.

The hypothesis according to which "democracies do not fight each other" (the so-called peace among democracies) is widely debated in international relations ${ }^{3}$. According to this hypothesis, even if democracies are often warprone, there have never been wars among consolidated democracies. Not everybody agree with this fact, but those that do agree also claim that if all states of the world were democratic, war may disappear. The normative

tan Democracy (Cambridge: Polity Press, 1998), Raffaele Marchetti, Global Democracy: For and Against (London: Routledge, 2008), Daniele Archibugi, The Global Commonwealth of Citizens: Toward Cosmopolitan Democracy (Princeton: Princeton University Press, 2008).

${ }^{2}$ Held, op. cit. in note 1.

${ }^{3}$ Michael Doyle, 'Kant, Liberal Legacies, and Foreign Affairs', Philosophy and Public Affairs, (Vol. 12 No. 3 \& 4, Summer 1983); Bruce Russett, Grasping the Democratic Peace (Princeton: Princeton University Press, 1993). 
implication is that to achieve the goal of peace it is necessary to induce internal democratization. Some policy-makers of democratic nations misunderstood the implications of this hypothesis and went so far to wage war against despotic regimes with the aim to force a regime change and to induce these countries to become democratic. The Iraq war started in 2003 is the most recent example.

Cosmopolitan democracy has an opposite approach: although it shares the desire to increase both the quantity of democratic states and the quality of their democratic procedures, it does not assume that the goal of peace can be achieved acting on the internal constitution of individual states only. Moreover, it argues that "exporting" democracy through war is contradicting the very nature of the democratic process since this requires to be built from below and not from above. For these reasons, cosmopolitan democracy suggests that an international system based on cooperation and dialogue is a fundamental condition to foster democratic progresses inside individual countries and also to allow peoples living under dictatorship to change endogenously their own regime. While the "peace among democracies" hypothesis tends to stress the causal link from internal democracy to international peace, cosmopolitan democracy points out at another equally important link: from international peace and cooperation to internal democracy.

To encourage the adoption of a more just and fair foreign policy and to increase the number of democratic states is certainly important. But something more is needed to safeguard the basic democratic principles of equality and participation, namely the willingness of states to undertake agreements respectful of the rule of law and of the procedures of democracy among states. These agreements sometimes involve states, as in the case of international organisations, but in more audacious circumstances might and should also involve individuals, allowing them to be at the same time citizens of a state and citizens of the world ${ }^{4}$.

For this reason, cosmopolitan democracy does not believe that the proposal of a League of Democracies, namely an international organization whose membership should be restricted to elected governments only, is very helpful. A League of Democracies will be another inter-governmental body which would not necessarily give voice to individuals. Rather than encouraging peoples living in autocratic states to demand a regime change in their own countries, it might have the effect of isolating them from the global society, making it more difficult to induce them to embrace and to fight for the democratic faith.

\footnotetext{
${ }^{4}$ Derek Heater, World Citizenship: Cosmopolitan Thinking and its Opponents (London: Continuum, 2002).
} 


\section{Genealogy and Associated Terms}

Cosmopolitan democracy can be seen as a modern revival of some peace theories. In particular, it is an attempt to refine and apply in the current political landscape some of the insights of institutional pacifism. Peace can be achieved through a variety of methods and one of them is strengthening international norms, covenants and organizations ${ }^{5}$. Several peace projects of the past, including those of Émeric Crucé, William Penn, the Abbé of Saint-Pierre, Jeremy Bentham, Immanuel Kant, and Claude-Henri de Saint-Simon, already designed international organizations with the function to sort out conflicts through peaceful means rather than through war. This body of thought had a crucial role in the creation of modern international organizations, including the League of Nations, the United Nations and the European Union ${ }^{6}$. It is today possible to reform these international organizations to accommodate a direct political role to citizens.

"Cosmopolitan democracy" might appear to be a strange combination of words. Both words were commonly used in classical Athens and originate from the Greek cosmos + polis and demos + kratos. However, while cosmopolis (literally, the city of the universe) was used to describe an ideal condition, democracy (the power of the many) was employed for very practical purposes, ie the everyday management of public affairs. Only selected elites could afford to be cosmopolitan, while on the contrary every adult free man belonged to the demos. But circumstances have dramatically changed, and globalisation provides the material conditions that could allow the expansion of the principles and procedures of democracy at the global level.

Other similar terms have been introduced in the literature. Democracy has been qualified as post-national ${ }^{7}$ to designate the development of forms of political organisation different from state-centred traditional ones; transnational ${ }^{8}$ to describe connections across non-governmental organisations and sub-state political units; or global ${ }^{9}$ to denote the need to democratise global governance. Cosmopolitan democracy is also closely linked to world federalism ${ }^{10}$, but it is less inclined to support concentration of coercive means in the hands of a central authority.

\section{Levels of democratic governance}

\footnotetext{
${ }^{5}$ Norberto Bobbio, Il problema della guerra e le vie della pace (Bologna: Il Mulino, 1984).

${ }^{6}$ Daniele Archibugi, 'Models of International Organization in Perpetual Peace Projects', Review of International Studies, (Vol. 18, No. 4, 1992).

7 Jürgen Habermas, The Postnational Constellation (Cambridge: Polity Press, 2001).

8 John S. Dryzek, 'Transnational Democracy', Journal of Political Philosophy, (Vol. 7, No. 1., 1999).

${ }^{9}$ Heikki Patomaki and Teivo Teivainen, A Possible World: Democratic Transformation of Global Institutions (London: Zed Books, 2004).

${ }^{10}$ Lucio Levi, Federalist Thinking (Langham, MD: University Press of America, 2008).
} 
While there are many overlaps in the use of the various terms, cosmopolitan democracy is best conceptualised as different, linked levels of governance: local, state-wide, inter-state, regional, and global.

The local dimension. Local networks are often active on the global level: since states seldom devolve competencies on specific issues to interlocal institutions, relevant actors are often forced to extend their activities beyond their assigned jurisdictions; as a result, more and more organisations - governmental and non-governmental - are being created that connect communities and local bodies not necessarily in the same state. Cosmopolitan democracy implies, therefore, the strengthening of the structure of local government when this entails crossing state borders.

The state dimension. Democratic states could be as much a laboratory as an agent of cosmopolitan democracy. For example, states today are called upon to grant rights to individuals - such as refugees and immigrants - who traditionally have been denied these rights. Yet democratic states face the dilemma as to whom they should regard as citizens: those who are born in a specific democratic community? Those who live in it and pay taxes? Or those who would simply like to be citizens of the community? Each state could already be a champion of cosmopolitanism by granting some rights also to individuals coming from different communities. A test of cosmopolitanism is today the way in which each community treats immigrants. Some states are more willing and better equipped to accommodate them and to provide specific rights or even to grant citizenship ${ }^{11}$.

The inter-state dimension. The existence of inter-governmental organisations (IGOs) - for example, the United Nations or the European Union - is an indicator of states' willingness to extend to the inter-state level certain democratic principles: formal equality between member states, public accountability and the rule of law. At the same time, however, it is an expression of the difficulties involved in achieving this ${ }^{12}$. Are IGOs democratic institutions? And, if are not, could they ever become so? Most IGOs are founded on the formal equality of their member states; this, in turn, guarantees each state the right to one vote irrespective of the size of its population and their involvement in decision-making, or of its level of political and military power. As a consequence, in the UN General Assembly, a myriad of small states whose population comprise just five per cent of the world total have the majority of votes. However, it would not be an improvement to endow the Assembly's majority to just six large states (China, India, United

\footnotetext{
${ }^{11}$ Seyla Benhabib, Another Cosmopolitanism (Oxford: Oxford University Press, 2006).

12 Robert Dahl, 'Can International Organizations be Democratic? A Skeptical View', in Ian Shapiro and Casiano Hacker-Cordón (eds.), Democracy's Edges (New York: Cambridge Universtity Press, 1999).
} 
States, Indonesia, Brazil and Russia), even if they represent more than half the world's population. IGOs are a typical case indicating that the majority principle should be reformulated to guarantee a fair democratic process.

The regional dimension. In many cases governance might be most appropriately conducted at the regional level. The most striking historical example of this is Europe, where slowly, and more or less continuously, a political system has developed which is capable not only of strengthening itself, but also of increasing the level of democracy within its member states. The European Union is distinguished from any other regional organisation by the presence of a parliament elected through universal suffrage, and by the success it had in enlarging the association from the first six to the current twenty-seven. Even within this region of solely democratic states, it is difficult to bridge democratic deficits. The demos may have very different views from the elites that have so far driven the political integration of the old continent. The recent referendums in France, the Netherlands and Ireland have bitterly shown that the demos at large is not necessarily favouring integration. But not even these referendums have stopped integration in Europe. Elsewhere, regional organisations have also increased and intensified their functions, with a particular focus on trading agreements. It has to be seen if, when and how these regional agreements will evolve in political terms through the creation of accountable and representative institutions.

The global dimension. For the past decade or so, non-state subjects have made their voices heard at various UN summits, as well as within such agencies as the IMF and WTO; this has given rise to the growing demand that international organisations should become increasingly representative and accountable to global public opinion. NGOs have no decision-making powers to date, and their role has been mostly of advocacy. But a level of governance that goes beyond the state's sphere of action is nevertheless gradually emerging. The United Nations and other international organisations, in spite of their inter-governmental character, have started to open their doors to non-governmental players. The call for global governance is strong in many areas: financial flows, immigration, environmental concerns, human rights, development aid ${ }^{13}$ (Koenig-Archibugi, 2002). Initiatives and campaigns pushing for greater accountability and democratisation are active with regard to each of these. If the existing international organisations continue to open their doors to this infant global civil society, the first seeds of democratic governance at the global level will be planted, and they will likely grow.

\footnotetext{
${ }^{13}$ Koenig-Archibugi, Mathias, 'Mapping Global Governance', in David Held and Tony McGrew (eds.), Governing Globalisation (Cambridge: Polity Press, 2002).
} 
The relations between the levels of governance. As both the levels and institutions of governance are increasing, the question that arises is: how can the various competencies be shared among these different bodies? Would the existence of institutions endowed with overlapping competencies give rise to new conflicts? The key concept is sovereignty, the foundation of the international legal system. Cosmopolitan democracy belongs to that school of thought that has regarded sovereignty as a dogma to be overcome. The assumption that a political or institutional subject should be exempted from responsibility for its actions is incompatible with the essence of democracy. Each political actor, whether a tyrant or a 'sovereign' people, must come to terms with other actors when competencies overlap. Cosmopolitan democracy shares the view that the concept of sovereignty should be replaced, within and between states, with that of constitutionalism. Conflicts over competence that arise as a result of the different levels of governance must be solved within the domain of a global constitutionalism and referred to jurisdictional bodies. These, in turn, must be based on an explicit constitutional mandate. To imagine that conflicts can be solved on a global level by constitutional and juridical procedures, rather than by force, is visionary. But it rests on the assumption that norms can be respected even in absence of a coercive power of last resort. The project of cosmopolitan democracy is thus identified with a much broader ambition: that of turning international politics from the realm of antagonism into the realm of agonism, that is, preserving conflicts but also allowing addressing them in a non-violent and dialogic manner.

\section{The roads to cosmopolitan democracy}

The project here summarized is certainly very ambitious. But the ambitions of the project should not hide that its politics is rooted in daily campaigns, and that there are a number of small and progressive targets that can be achieved. There is a wealth of campaigns for the progressive transformation of international affairs which somehow need to be associated to a vision of a desirable new world order and the principal aim of cosmopolitan democracy is just to provide a framework in which these campaigns could be located. Three specific lines of actions will be reviewed below: the rule of law, the participation of stake-holders and the possibility to achieve global representation thorough a world parliament.

Rule of law. - The rule of law is an essential condition of any democratic system. Within the cosmopolitan democracy framework, the rule of law does not necessarily imply the creation of a coercive supra-national power. In fact, several international organizations, including the European Union and the United Nations, already have complex legal norms and an embryonic judicial power. The decisions of this judicial power are often ignored and this is hardly surprising given the lack of a coercive power. Never- 
theless, if international norms and jurisdiction become more sophisticated, it will be increasingly difficult for governments to ignore them.

Over the last decade, the desire to reinforce a global rule of law has mostly focused on international criminal law. The creation of several ad hoc international courts and, above all, the foundation of the International Criminal Court (ICC) have generated new hopes to hold politicians accountable for their actions. Indeed, the ICC is the most significant institutional innovation introduced of the last twenty years. Much should still be done in order to make the Court fully operative, and to induce all countries to accept its jurisdiction. But it is already possible to assess its first few years of activities. So far, the ICC has mostly acted on African suspected culprits, and on insurgents fighting against, and denounced by, incumbent governments (the case opened against the Sudanese President Omar al-Bashir is a significant exception). All investigations so far undertaken are well documented, but the coverage is too selective. There is the danger that the ICC will be perceived as an instrument of incumbent governments against rebels and another burden of the white man over the black man. Those who hoped that the ICC could also be an instrument in defence of the weaker actors against the most powerful ones have so far been disappointed. There is therefore the need to balance the action of the Court to cover also cases in which the crimes are committed by Western individuals and powers.

The interest for the ICC has somehow darkened an equally important aspect, namely the need to address inter-state controversies through legal instruments. The International Court of Justice (ICJ), the body delegated to address these controversies, is highly under-used mostly because its activation is possible only when both parties in a dispute are willing to accept its own jurisdiction. Unfortunately, this happens very seldom and for insignificant controversies. If we read the sentences and the opinions provided by the Court, we will have a very unfaithful description of the major events of world politics since 1946. The Vietnam war, the invasions of Hungary and Czechoslovakia, the Iraq war, the legitimacy of nuclear weapons and many other key historical events have not received any attention from the Court for the very simple reason that states were not willing to submit the case to its judgement.

A major expansion of the global rule of law will require empowering the ICJ with compulsory jurisdiction ${ }^{14}$. In such a case, the Court will not any longer act as a "referee" among two states, but as a proper Tribunal. This does not necessarily imply that the ICJ will have the power to enforce its own sentences. But even in absence of enforcement, a sentence denouncing

\footnotetext{
${ }^{14}$ Richard Falk, Law in an Emerging Global Village: A Post-Westphalian Perspective (Ardsley: Transnational Publishers, 1998).
} 
the behaviour of some states will have an important impact on international relations.

The Role of Stake-Holders. - Decision-making is not necessarily based on territorial communities. As argued above, there are an increasing number of areas in which political problems are non-territorial or involve stake-holders in very different capacities. Human communities may need to have political participation because they speak the same language in different continents, they have similar health problems or share similar values ${ }^{15}$. The idea that becoming a sovereign territorial state is the only option for these groups of peoples to apply democratic values and norms is baroque. Different forms of political representation could be tried ${ }^{16}$ allowing these communities to benefit from democratic procedures.

The number of transnational actors that are in charge of specific domains is increasing as it is the number of administrative bodies involving both public and business members. Transnational movements for social justice have already experimented ways to link subjects across borders.

The rise of new players claiming political legitimacy leads to the question: who are the stakeholders? For good and for bad, the organization of political communities based on states has provided an answer: it is the state that decides at the same time who are the citizens inside and that represents them outside.

If the state is complemented with other forms of political representation, it will be much more difficult to assess who are the stakeholders. Are the stakeholders of the oil business the consumers of the industrial society or citizens of oil-producing countries? If the answer is likely to be "both of them", it should also be discussed what should be the relative weight that the relative categories should have in the political process. This in turn calls for the need to get a representative body with the authority and the competence to distribute political competence to the various stake-holders. According to the cosmopolitan democracy model, such an authority should be a world parliament.

World Parliament. - The dream of a world parliament is very old. As many dreamy ideas came back into the fore in the last years ${ }^{17}$. Such institution will be the natural and most effective way to bring together the peoples of the earth, allowing them to deliberate on common issues. It is unlikely

${ }^{15}$ Carol Gould, Globalizing Democracy and Human Rights (Cambridge: Cambridge University Press, 2004).

${ }^{16}$ John Dryzek, Deliberative Global Politics, (Cambridge, Polity Press, 2006), Raffaele Marchetti, Global Democracy: For and Against (London: Routledge, 2008).

${ }^{17}$ Richard Falk, Andrew Strauss, 'The Deeper Challenges of Global Terrorism: A Democratizing Response", in Daniele Archibugi (ed.), Debating Cosmopolitics (London: Verso, 2003). 
that such an organ will have effective powers (at least in the short period), but even as a forum of the global public opinion it could have an important role in identifying what are the real and the imagined differences among various civilisations. Such a new institution should complement the UN General Assembly. In the last decade, such a proposal has been supported by a variety of authorities and institutions (for a list of the endorsers, see the Campaign for the Establishment of a United Nations Parliamentary Assembly, at http://en.unpacampaign.org/news/374.php).

The basic function of a World Parliament is to allow individuals to have voice and representation in global affairs that is not associated to the voice and representation the government of the state they belong to. This, in turn, is based on the assumption that the agendas of governments, even when democratically elected, do not necessarily correspond to the interest and the will of their population. A common forum of the citizens of the world is more likely to find workable solutions in cases of controversies.

Some of these plans have envisaged a Parliament made of about 600 deputies with a criterion of representation that will favour delegations elected in small nations. Jeffrey Segall has suggested that all states with less than one million inhabitants should have a member of parliament, and the larger state, China, should have about 30 deputies. According to Charter, the UN General Assembly can establish such an organ. Such a legislative Assembly should not necessarily be involved on every aspects of global political life, but it would better concentrate on the most relevant issues either for their impact on global life (such as the environment) or for their political significance (such as major violations of human rights). On other occasions, the World Parliamentary Assembly may limit itself to provide suggestions on what would be the most appropriate constituency to address issues that cut across borders.

There are many transitional devices that can lead to the establishment of a directly elected World Parliament. The three principal ones are: i) the formation of an Assembly of the few thousand of International NonGovernmental Organisations recognized by the UN; ii) a Parliament made of representatives nominated by National Parliaments. The European Parliament, prior to the first direct election in 1979 followed this route; iii) a treaty among a selected number of like-minded states, in the hope that other states will follow. The institution of the ICC has followed this route.

\section{Conclusions}

Cosmopolitan democracy started to be formulated on the hope that the fall of the Berlin Wall will lead to build a more democratic world order. These hopes have, so far, been frustrated. One obvious and major constrain is the existence of a variety of tyrannical governments. But there is also 
another, and less evident constrain, and this is represented by the fact that the club of states that dominate the world - all of which with elected governments - too often pursue a foreign policy that is incompatible with their own internal constitution. If democratic states will consistently apply their constitutional principles also to foreign polity, in the short or medium run there will be no single state that could resist the internal pressures to introduce and/or expand democracy. And, at the same time, the hegemonic power of a few states will be seriously constrained. Cosmopolitan democracy argues that internal democratization is also strictly associated to the global landscape: the more channels of dialogue and participation will be available, and the more it will be possible to obtain political participation within states. The political proposals made are achievable if there is the genuine political willingness to move in this direction.

Daniele Archibugi is Professor of Innovation, Go ernance, and Public Policy at the University of London, Birbeck College, and Research Director at the Italian National Research

Council in Rome. 